\title{
Kompetensi Guru PAUD dalam PJJ melalui Pelatihan Pendekatan STEAM pada Masa Covid-19
}

\author{
Komala ${ }^{1 凶}$, Rohmalina $^{2}$ \\ Pendidikan Guru Pendidikan Anak Usia Dini, Institut Keguruan dan IImu Pendidikan Siliwangi \\ Bandung \\ DOI: $\underline{30.31004 / a u l a d . v 4 i 1.96}$
}

Corresponding author: [putrikomala0301@gmail.com]

Article Info Abstrak

Kata kunci:

Kompetensi Guru PAUD

Pembelajaran Jarak Jauh

(PJJ)
Guru perlu memiliki kompetensi dalam memilih dan menggunakan metode pembelajaran yang tepat untuk menyampaikan materi secara jarak jauh. Mengingat pentingnya peningkatan kompetensi guru dalam pembelajaran jarak jauh (PJJ) maka perlu adanya pelatihan. Penelitian ini memiliki tujuan untuk mengetahui peningkatan kompetensi guru dalam pembelajaran jarak jauh (PJJ) melalui pelatihan pendekatan pembelajaran berbasis STEAM kepada guru-guru PAUD pada Masa Covid-19. Metode yang digunakan adalah quasi eksperimen. Penelitian ini menghasilkan beberapa temuan mengenai peningkatan kompetensi guru melalui pelatihan pendekatan STEAM pada guru anak usia dini. Hasil penelitian diperoleh bahwa rata-rata peningkatan kompetensi guru dalam PJJ sebelum pembelajaran tidak berbeda secara signifikan antara kelas eksperimen dan kontrol.

\section{Abstract}

Keywords:

Pelatihan Pendekatan Pembelajaran

STEAM
Teachers need to have competence in selecting and using appropriate learning methods to deliver material remotely. Given the importance of increasing teacher competence in distance learning (PJJ), it is necessary to have training. This study aims to determine the increase in teacher competence in distance learning (PJJ) through STEAM-based learning approach training for PAUD teachers during the Covid-19 Period. The method used is a quasi experiment. This study resulted in several findings regarding increasing teacher competence through training in the STEAM approach to early childhood teachers. The results showed that the average increase in teacher competence in PJJ before learning did not differ significantly between the experimental and control classes. 


\section{PENDAHULUAN}

Guru merupakan salah satu komponen penting dalam pendidikan. Bagaimana bangsa Indonesia di masa depan sangat bergantung pada kualitas guru. Kompetensi utama guru pun saat ini belum menggembirakan. Mengingat masih banyak guru yang cara mengajarnya kurang baik seperti cara mengajar di kelas membosankan. Sehingga perlu peningkatan kompetensi guru. Undang-undang Nomor 14 Tahun 2005 Tentang Guru dan Dosen, dan Peraturan Pemerintah Nomor 18 Tahun 2007 Tentang Guru. Peraturan ini menunjukkan bahwa guru merupakan salah satu komponen penting dalam proses pendidikan. Namun, kenyataan di lapangan menunjukkan kurangnya ketersediaan guru yang kompeten, termasuk Guru Pendidikan Anak Usia Dini (PG-PAUD)

Menurut Usman (Usman, 2003:5) guru merupakan jabatan atau profesi yang memerlukan keahlian atau kompetensi tertentu dalam rangka melaksanakan tugas dan fungsinya sebagai guru.Tanpa memiliki keahlian, kemam-puan atau kompetensi tertentu yang harus dimilikinya, guru tidak dapat menjalankan tugas dan fungsi profesinya sebagai guru.

Mulyasa (Mulyasa, 2004:38) menyatakan bahwa kompetensi merupakan perpaduan unsur pengetahuan, keterampilan, nilai, sikap, yang direfleksikan dalam kebiasaan berpikir dan bertindak. Menurut Fahrudin (Fahrudin, 2012:2) Kompetensi guru diartikan sebagai seperangkat pengetahuan dan ketrampilan yang dimiliki, dihayati dan dikuasai oleh seorang guru yang meliputi perilaku kognitif, afektif dan psikomotor dengan sebaik-baiknya untuk melaksanakan tugas guru secara profesional. Kompetensi guru adalah kemampuan dan kewenangan guru dalam melaksanakan profesi keguruannya. Sedangkan menurut Ananda (Ananda, R,2018:39) kompetensi guru Indonesia meliputi kompetensi pedagogik, kompetensi kepribadian,kompetensi sosial dan kompetensi professional.

Kompetensi guru pada saat ini sangat penting apalagi dengan adanya pademi covid-19 yang melahirkan beberapa pandangan mengenai pelaksanaan pembelajaran yang lebih mengutamakan kesehatan anak bangsa sehingga perlu adanya kompetensi guru dalam menyampaikan pembelajaran melalui metode, pendekatan dan teknik pembelajaran dengan melaksanakan protokoler kesehatan. Sehingga pembelajaran tidak melalui tatap muka langsung melainkan melalui jarak jauh. Di sinilah perlu adanya perubahan pembelajaran tradisional menuju ke pembelajaran yang lebih meningkatkan daya berpikir kritis. Salah satu bentuk pembelajaran yang lebih meningkatkan berpikir kritis yaitu pendekatan pembelajaran STEAM. endekatan STEAM merujuk kepada empat komponen ilmu pengetahuan yaitu pengetahuan, teknologi, teknik, dan matematika (Permanasari,2016).

Menurut Depdiknas (2005:90) dalam Peraturan Pemerintah Republik Indo-nesia Nomor 19 Tahun 2005 Tentang Stan-dar Nasional Pendidikan pada penjelasan Pasal 28, ayat (3), butir a, sudah secara jelas mendeskripsikan bahwa Kompetensi Pedagogik adalah kemampuan mengelola pembelajaran peserta didik, yang meliputi pemahaman terhadap peserta didik, pe-rancangan dan pelaksanaan pembelajaran, evaluasi hasil belajar, dan pengembangan peserta didik untuk mengaktualisasikan berbagai potensi yang dimilikinya.

Kompetensi Pedagogi meliputi (1) Menguasai karakteristik peserta didik dari aspek sik, moral, spiritual, sosial, kultural, emosional, dan intelektual. (2) Menguasai teori belajar dan prinsip-prinsip pembelajaran yang mendidik; (3) Mengembangkan kurikulum yang ter-kait dengan mata pelajaran yang diam-pu; (4) Menyelenggarakan pembelajaran yang mendidik; (5) Memanfaatkan teknologi informasi dan komunikasi untuk kepentingan pembelajaran; (6) Memfasilitasi pengembangan potensi peserta didik untuk mengaktualisasi-kan berbagai potensi yang dimiliki; (7) Berkomunikasi secara efektif, empatik, dan santun dengan peserta didik; (8) Menyelenggarakan penilaian dan eva-luasi proses dan hasil belajar;(9) Memanfaatkan hasil penilaian dan eva-luasi untuk kepentingan pembelajaran; (10) Melakukan tindakan reflektif untuk peningkatan kualitas pembelajaran

Adanya pademi covid-19 melahirkan beberapa pandangan mengenai pelaksanaan pembelajaran yang mengutamakan kesehatan anak bangsa dengan melaksanakan protokoler kesehatan. Sehingga pembelajaran dilaksanakan tidak melalui tatap muka langsung melainkan melalui jarak jauh. Selain itu 
juga dapat dilaksanakan melalui penerapan reformasi pendidikan. Pembelajaran untuk meningkatkan daya berpikir kritis dalam pendidikan dapat melalui pendekatan STEAM. Kemampuan berpikir kritis salah satu dimensi dari proses kognitif yang diperlukan untuk menyelesaikan permasalahan abad 21 dan merupakan arah perkembangan pembelajaran secara global (Birgili, 2015).

STEAM bisa dikenalkan pada anak sejak dini dengan peralatan sederhana dan murah di sekitar kita. Sehingga para pendidik/guru maupun orang tua dapat membantu menyiapkan anak tumbuh menjadi sosok yang kritis, analitis, kreatif dan inovatif. Karena dunia anak adalah dunia yang penuh dengan rasa ingin tahu terhadap apa yang mereka rasakan. Anak pada umumnya akan akan bersemangat dalam menggali pengetahuan tentang hal-hal melalui panca indera mereka. Meskipun demikian, sebagian besar pendidik kadang-kadang merasa belum siap degan pertanyaan-pertanyaan kompleks, kritis, analisis dan kreatif mengenai sains, teknologi, seni dan hal-hal di luar nalar yang muncul pada anak. Sehingga guru perlu memacu diri untuk meningkatkan kompetensinya dalam mengajar, baik sebagai pendidik, pelatih, pembimbing maupun pengasuh sehubungan dengan perkembangan teknologi dan informasi yang begitu pesat. Untuk mengimbangi kemampuan berfikir anak jaman milenial ini guru perlu memiliki kompetensi mengajar seperti kemampuan menyesuaikan diri dalam membantu pembelajaran siswa, dapat menerangkan teori pelajaran secara jelas pada anak, ini yang berdasarkan hasil penelitian sebelumnya bahwa anak-anak saat ini ada pada generasi 4.0 ini, dimana kecerdasan anak jaman sekarang lebih cerdas melebihi kemampuan anak jaman sebelumnya yaitu kemampuan/kecerdasan anak sekarang melebihi kemampuan/kecerdasan orang tuanya sehingga dikenal dengan anak pada generasi 4.0.

Tujuan dari penelitian ini adalah untuk mengetahui peningkatan kompetensi pedagogi guru dalam pembelajaran jarak jauh (PJJ) melalui pelatihan pendekatan STEAM sehingga dapat mengantarkan anak sesuai dengan potensi, bakat dan minatnya sejak dini. Karena dunia anak adalah Dunia yang penuh dengan keingintahuan terhadap apa yang mereka lihat dan rasakan. Pada umumnya anak akan bersemangat dalam menggali pengetahuan tentang hal-hal melalui pancaindera mereka. Meskipun demikian, sebagian besar pendidik kadang-kadang merasa belum siap dengan pertanyaan-pertanyaan kompleks, kritis, analisis dan kreatif mengenai sains, teknologi, seni dan hal-hal diluar nalar yang muncul pada anak. Sehingga guru perlu memacu diri untuk meningkatkan kompetensinya dalam mengajar, baik sebagai pelatih, pembimbing maupun pengasuh sehubungan dengan perkembangan teknologi dan informasi yang begitu pesat untuk mengimbangi kemampuan berfikir anak jaman milenial ini yang berdasarkan hasil penelitian sebelumnya bahwa anak-anak saat ini ada pada generasi 4.0, dimana kecerdasan anak jaman sekarang lebih cerdas melebihi pengetahuan kemampuan anakjaman sebelumnya bahkan kemampuan/kecerdasan anak sekarang melebihi kemampuan/kecerdasan orangtuanya sehingga dikenal dengan anak pada generasi 4.0 .

\section{METODE PENELITIAN}

Penelitian ini dilaksanakan kepada guru-guru Pendidikan anak usia dini yang ada di Kecamatan Padalarang Kabupaten Bandung Barat tahun pelajaran 2020/2021. Metode penelitian menggunakan pendekatan penelitian kuantitatif yakni metode kuasi eksperimen dengan desain penelitian yang digunakan (nonequivalent control groups design) pada guru-guru Pendidikan Anak Usia Dini yang berada di Kecamatan Padalarang Kabupaten Bandung Barat. Stouffer (1950) dan Campbell (1957) dalam Dicky Hastjarjo (2008:4) merumuskan eksperimen kuasi (quasi experiment) sebagai eksperimen yang memiliki perlakuan, pengukuran dampak, unit eksperimen, tetapi tidak menggunakan penugasan acak untuk menciptakan pembandingan dalam rangka menyimpulkan perubahan yang disebabkan perlakuan.

Hal ini seiring dengan pendapat Ningsih et.,al:2016 bahwa metode quasi eksperimen, merupakan penelitian dengan menggunakan metode yang memberikan perlakuan dengan tidak memberikan penempatan secara acak (Ningsih et al., 2016). Dalan penelitian ini mengambil sampel sebanyak 25 guru Pendidikan anak usia dini yang berada di Bandung Barat sebagai subjek dari Guru-guru yang ada di 
Bandung Barat yang mana terbagi menjadi dua kelas yaitu kelas control dan kelas eksperiment. Dalam pelaksanaan penelitian kelas control masih menggunakan metode pembelajaran konvensional (tidak diberikan perlakuan) sedangkan kelas eksperiment kelas yang diberikan perlakuan dengan menggunakan metode pelatihan pendekatan STEAM.

Sebelum pelaksanaan diklat pendekatan pembelajaran STEAM peneliti melaksanakan pretest baik kepada kelas eksperimen guru-guru di kecamatan Padalarang Kabupaten Bandung Barat yang mengikuti pelatihan Kompetensi guru dalam pembelajaran jarak jauh (PJJ) melalui pendekatan STEAM maupun kelas control yaitu guru-guru yang tidak mengikuti diklat peningkatan kompetensi guru dalam pembelajaran jarak jauh melalui pendekatan pembelajaran STEAM. Setelah itu peneliti memberikan perlakuan kepada kelas eksperimen yaitu guru-guru di kecamatan Padalarang Kabupaten Bandung Barat dengan memberikan pelatihan pendekatan STEAM untuk pembelajaran Jarak jauh (PJJ). Setelah pelatihan peneliti melakukan pendampingan kepada guru-guru pendidikan anak usia dini dalam pembelajaran melaui virtual zoom meeting dan video call grup.

Penelitian ini menghasilkan beberapa temuan mengenai peningkatan kompetensi guru melalui pelatihan pendekatan STEAM pada guru anak usia dini. Pendekatan pembelajaran STEAM pada guru Anak Usia Dini di Kecamatan Padalarang Kabupaten Bandung Barat. Mengingat masih pada masa pademi pelaksanakan pelatihan melalui webinar yaitu pelaksanaan pelatihan melalui virtual (zoom meeting) kemudian untuk prakteknya pun melalui pendampingan virtual zoom meeting, video call wa grup dan hasil yang telah diterapkan pada kegiatan pelatihan ini. Melalui kegiatan ini, beberapa potensi yang ada pada guru-guru anak usia dini di Kecamatan Padalarang Kabupaten Bandung Barat nampak jelas.

Untuk mengetahui peningkatan kompetensi guru dalam pembelajaran jarak jauh (PJJ) ini kami melakukan observasi dan pendampingan kepada kelompok guru yang diberi perlakuan (kelompok eksperimen) yaitu guru-guru yang mengikuti diklat pembelajaran STEAM melalui virtual (zoom meeting dan vieo call wa grup). Tetapi kepada kelompok control yaitu guru-guru yang tidak mengikuti diklat STEAM kami melakukan observasi pretes dan melalui zoom meeting atau Video Call. Setelah itu kami melakukan observasi kepada guru untuk mengetahui pengaruh menerapkan pembelajaran STEAM melalui virtual (zoom meeting), Video Call WA grup kepada guru-guru yang telah mengikuti diklat pendekatan STEAM. Berdasarkan pendampingan kepada guru yang telah mengikuti pelatihan pendekatan STEAM secara virtual melalui zoom meeting, video call dan WA grup, menunjukkan bahwa guru yang telah melaksanakan pelatihan pendektan STEAM dapat melaksanakan pembelajaran jarak jauh lebih menarik, kreatif dan inovatif sehingga pelaksanaan pembelajaran jarak jauh dengan mempraktekan pendekatan STEAM lebih efektif dan efisien. Nampak ada hasil karena pencapaian tujuan pelatihan lebih efektif dan maksimal.

\section{HASIL DAN PEMBAHASAN}

Berdasarkan hasil penelitian kondisi awal kompetensi pedagogic guru-guru pendidikan anak usia dini yang ada di Kecamatan Padalarang Kabupaten Bandung Barat pada tahun ajaran 2020/2021 yang nyata di lapangan berada pada tingkat rendah dan sedang. Hal ini terlihat dari hasil pretes kompetensi pedagogi guru Pendidikan anak usia dini sebelum diberikan perlakuan rata-rata 62,55\%. . Artinya kedua kelas dapat dikatakan memiliki kemampuan awal yang hampir sama. Setelah dilakukan pegamatan pada kedua kelas dengan perakuan yang berbeda, yakni kelas eksperimen diberikan diklat pendekatan pembelajaran STEAM dan kelas kontrol tidak diberikan perlakuan, dilakukan postest dan pada kelas eksperimen diperoleh nilai rata-rata sebesar 122,32 dengan standar deviasi 4,86. Sedangkan untuk hasil posttest kelas kontrol diperoleh nilai rata-rata kompetensi pedagogic sebesar 101,79 dengan standar deviasi 6,04.

Jika kita bandingkan peningkatan yang terjadi pada kedua kelas maka diperoleh gain antara hasil pretest dan postest, gain ini untuk selanjutnya diolah menjadi gain yang sudah ternormalisasi atau disebut $\mathrm{N}$-gain. Untuk kelas eksperimen diperoleh $\mathrm{N}$-gain sebesar 0,83 dengan standar deviasi 0,12 
sedangkan untuk kelas kontrol diperoleh $\mathrm{N}$-gain sebesar 0,60 dengan standar deviasi 0,12. Berdasarkan kategori (Hake, 1999, pp. 1-7) diperoleh bahwa peningkatan kompetensi guru pendidik anak usia dini pada kelas eksperimen tergolong kategori tinggi sedangkan peningkatan kompetensi guru pada kelas kontrol tergolong sedang.

Sebelum data peningkatan kompetensi pendidik anak usia dini diolah lebih lanjut, terlebih dahulu dilakukan uji asumsi statistik. Uji asumsi statistik yang dilakukan yaitu uji normalitas dan uji homogenitas varians. Uji normalitas dan homogenitas varians dilakukan terhadap pretest, data N-Gain. Uji normalitas dan homogenitas varians data pretest dilakukan untuk mengetahui jenis statistik uji kesamaan rata-rata data pretest. Analisis ini bertujuan untuk menguji bahwa tidak adanya perbedaan terhadap kompetensi guru dalam pembelajaran PJJ awal kelas Kelompok Eksperimen dan Kelompok Kontrol sebelum pelatihan pendekatan STEAM.

Jika data memenuhi syarat normalitas dan homogenitas, maka uji kesamaan rata-rata dilakukan dengan menggunakan uji-t, sedangkan jika data normal tetapi tidak homogen uji kesamaan rataan menggunakan uji-t', dan untuk data yang tidak memenuhi syarat normalitas, uji kesamaan rata-rata menggunakan uji non-parametrik, uji Mann-Whitney U.

Berdasarkan uji-t untuk kompetensi pedagogi guru pendidik anak usia dini sebesar 0,241. Nilai Sig. > 0,05 sehingga $\mathrm{HO}$ diterima, artinya tidak terdapat perbedaan rata-rata pretest yang signifikan baik pada kompetensi guru pendidik anak usia dini untuk Kelompok Eksperimen dan Kelompok Kontrol. Jadi, dapat ditarik kesimpulan bahwa sebelum perlakuan pelatihan dilakukan kedua kelas memiliki kompetensi pedagogi guru pendidik anak usia dini yang setara. Oleh karena itu, syarat bahwa kelompok eksperimen dan kelompok kontrol memiliki kemampuan awal yang sama dapat terpenuhi. Sehingga perlu dianalisis secara komprehensif untuk pembuktian hipotesis penelitian. Hipotesis penelitian pertama berbunyi: "Peningkatan kompetensi guru pendidik anak usia dini Kelompok Eksperimen lebih baik dibandingkan dengan kompetensi guru pedidik anak usia dini Kelompok Kontrol".

Berdasarkan hasil perhitungan dan analisis maka diperoleh data bahwa nilai Sig. $=0,000$. Karena nilai Sig. < 0,05 maka HO ditolak, hal ini menunjukkan bahwa terdapat perbedaan peningkatan kompetensi guru pendidik anak usia dini anak yang signifikan antara kompetensi guru Pendidik anak usia dini Kelompok Eksperimen dengan anak Kelompok Kontrol. Rata-rata peningkatan kompetensi guru pendidik anak usia dini pada Kelompok Eksperimen yaitu 0,91 lebih besar dibandingkan kelompok kontrol sebesar 0,63 , selisih perbedaan tersebut sebesar 0,28. Hal ini menunjukkan bahwa peningkatan kompetensi guru pendidik anak usia dini Kelompok Eksperimen lebih baik dibandingkan dengan anak Kelompok Kontrol. Setelah diketahui bahwa peningkatan kemampuan kelas eksperimen lebih baik dari kelas kontrol, selanjutnya akan dilihat seberapa besar pengaruh Kelompok Eksperimen dalam meningkatkan literasi etnomatika anak usia dini dengan menggunakan effect size yaitu sebagai berikut. Berdasarkan perhitungan tersebut diperoleh besar effect size sebesar 0,91. Ukuran tersebut berada pada kategori besar sehingga dapat disimpulkan bahwa perlakuan pada Kelompok Eksperimen memiliki pengaruh yang besar dalam meningkatkan kompetensi guru pendidik anak usia dini.

Penelitian ini menghasilkan beberapa temuan terkait literasi kompetensi guru pendiidk anak. Berikut ini akan dibahas secara rinci mengenai hasil penelitian tersebut. Berdasarkan hasil penelitian diperoleh bahwa rata-rata kompetensi guru pendidik anak usia dini sebelum pembelajaran tidak berbeda secara signifikan antara kelas eksperimen dan kontrol. Hal ini berarti bahwa sebelum pelatihan pendekatan STEAM dilaksanakan, tidak terdapat perbedaan kemampuan awal antara dua kelas tersebut. Selanjutnya, setelah tindakan dilaksanakan, dilakukan posttest untuk mengetahui gambaran akhir setelah tindakan di kedua kelas. Hasil posttest pada kompetensi guru menunjukkan bahwa terdapat peningkatan yang lebih besar pada kelas eksperimen dibandingkan dengan kelas kontrol. Rata-rata posttest kelas eksperimen yaitu 122,32 dengan persentase pencapaian yaitu sebesar 91\% sedangkan untuk kelompok kontrol rata-ratanya yaitu 101,79 dengan persentase pencapaian yaitu sebesar $62,55 \%$. Menunjukkan bahwa setelah tindakan dilaksanakan diperoleh bahwa pencapaian pada kelas eksperimen 
lebih tinggi dibandingkan dengan kelas kontrol. Hal ini dikarenakan pada kelas eksperimen guru dibekali pelatihan pendekatan STEAM untuk meningkatkan kompetensi guru dalam menguasai karakteristik peserta didik dari aspek sik, moral, spiritual, sosial, kultural, emosional, dan intelektual , menerangkan teori pelajaran secara jelas pada anak, menggunakan pendekatan tertentu (STEAM) dengan strategi , teknik, metode yg kreatif, mengembangkan kurikulum ( menyusun silabus, RPP sesuai kebutuhan), guru tdk sekedar menyampaikan pelajaran tetapi melakukan pendampingan, guru mengembangkan potensi anak (peserta didik), memanfaatkan teknologi informasi dan komunikasi untuk kepentingan pembelajaran, guru melakukan dan penilaian dan evaluasi terhadap efektivitas pembelajaran yg dilakukan

Hasil penelitian menunjukkan bahwa tindakan pada kelas eksperimen melalui pelatihan pendekatan STEAM mampu meningkatkan kompetensi pedagogi guru dalam pembelajaran jarak jauh yang lebih baik dibandingkan dengan kelas kontrol. Hal ini terjadi karena guru dibekali kompetensi pedagogi dalam pembelajaran jarak jauh (PJJ) melalui pelatihan pendekatan STEAM. Selain itu, pada tindakan ini guru diajak untuk meningkatkan kompetensi pedagogi guru melalui pendampingan pendekatan STEAM yang diaplikasikan dalam pembelajaran jarak jauh kepada anak langsung dengan memanfaatkan media yang ada sederhana dan nyata di lapangan.

Adapun hasil penelitian berdasarkan indikator dapat digambarkan pada paragraf berikutnya.

Tabel 1. Data Nilai Indikator Guru dapat Menguasai karakteristik peserta didik dari aspek sik, moral, spiritual, sosial, kultural, emosional, dan intelektual

\begin{tabular}{clccc}
\hline No & Nama & Pretest & Postest & Prosentase kenaikan \\
\hline 1 & Al & 65 & 85 & $30.77 \%$ \\
2 & CN & 64 & 76 & $18.75 \%$ \\
3 & DS & 73 & 85 & $16.44 \%$ \\
4 & FK & 68 & 78 & $14.71 \%$ \\
5 & IF & 65 & 80 & $23.08 \%$ \\
6 & LQN & 64 & 88 & $37.50 \%$ \\
7 & NNA & 55 & 76 & $38.18 \%$ \\
8 & RF & 53 & 78 & $47.17 \%$ \\
9 & RA & 56 & 70 & $25.00 \%$ \\
10 & RH & 67 & 86 & $28.36 \%$ \\
11 & TL & 59 & 78 & $32.20 \%$ \\
12 & AYN & 68 & 89 & $30.88 \%$ \\
13 & CN & 66 & 86 & $30.30 \%$ \\
14 & CW & 68 & 76 & $11.76 \%$ \\
15 & IN & 58 & 86 & $48.28 \%$ \\
16 & ME & 54 & 70 & $29.63 \%$ \\
17 & NJ & 70 & 86 & $22.86 \%$ \\
18 & RAN & 58 & 75 & $29.31 \%$ \\
19 & TD & 54 & 76 & $40.74 \%$ \\
20 & YN & 67 & 86 & $28.36 \%$ \\
21 & DS & 56 & 75 & $33.93 \%$ \\
22 & MA & 64 & 80 & $25.00 \%$ \\
23 & NAR & 65 & 82 & $26.15 \%$ \\
24 & RR & 66 & 84 & $27.27 \%$ \\
25 & TR & 59 & 72 & $22.03 \%$ \\
& Rata-rata & 62.48 & 80.12 & $28.75 \%$ \\
\hline
\end{tabular}


Aulad : Journal on Early Childhood, 4(1) 2021, Pages 38-52

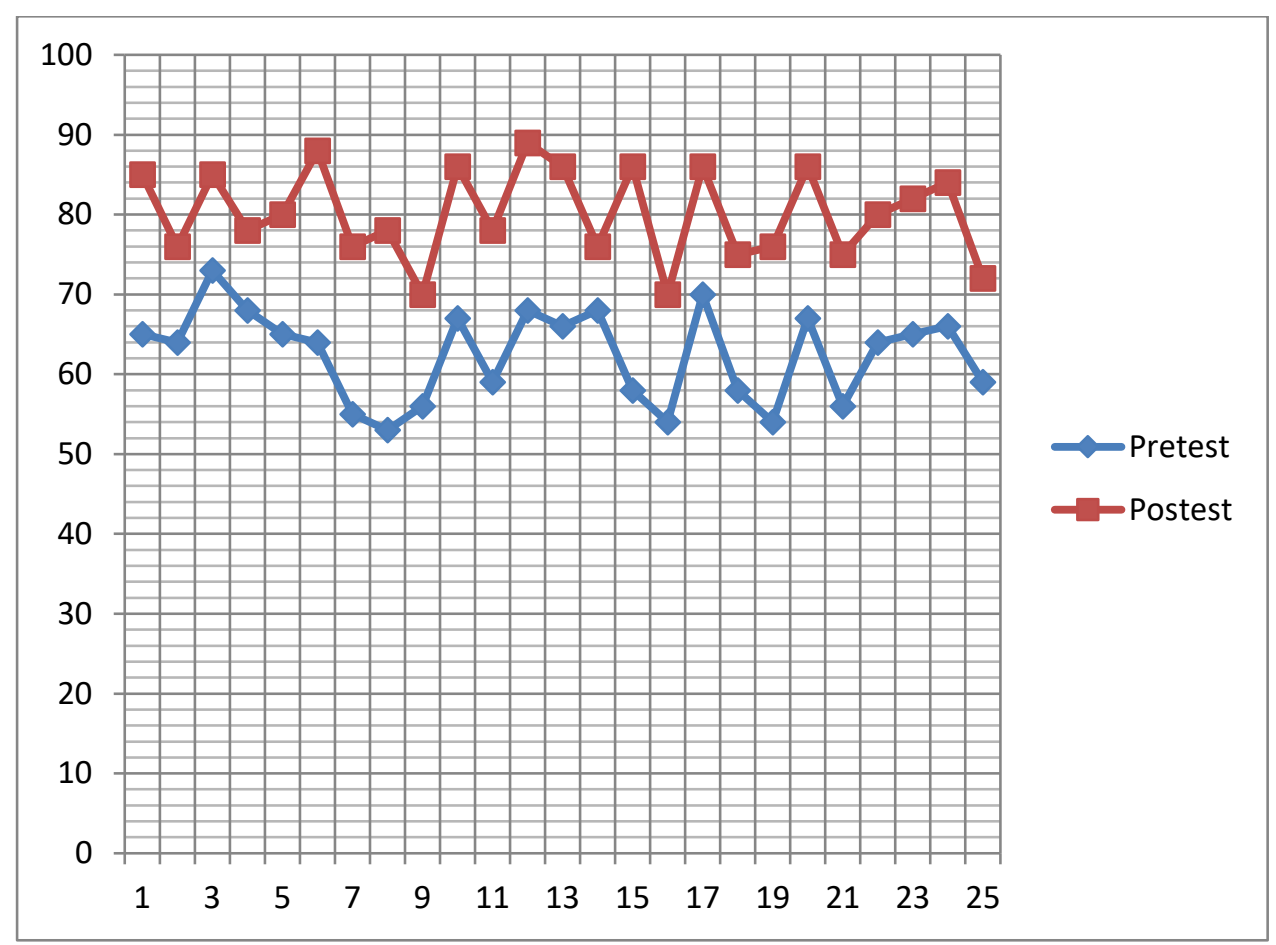

Gambar 1. Grafik peningkatan pretest dan postest pada Indikator: Guru dapat Menguasai karakteristik peserta didik dari aspek sik, moral, spiritual, sosial, kultural, emosional, dan intelektual

Tabel 2. Data Nilai Indikator Guru dapat menerangkan teori pelajaran secara jelas pada anak

\begin{tabular}{clccc}
\hline No & Nama & Pretest & Postest & Prosentase kenaikan \\
\hline 1 & Al & 70 & 89 & $27.14 \%$ \\
2 & CN & 58 & 86 & $48.28 \%$ \\
3 & DS & 54 & 76 & $40.74 \%$ \\
4 & FK & 67 & 86 & $28.36 \%$ \\
5 & IF & 56 & 70 & $25.00 \%$ \\
6 & LQN & 64 & 86 & $34.38 \%$ \\
7 & NNA & 65 & 75 & $15.38 \%$ \\
8 & RF & 66 & 76 & $15.15 \%$ \\
9 & RA & 59 & 86 & $45.76 \%$ \\
10 & RH & 65 & 85 & $30.77 \%$ \\
11 & TL & 64 & 76 & $18.75 \%$ \\
12 & AYN & 73 & 85 & $16.44 \%$ \\
13 & CN & 68 & 78 & $14.71 \%$ \\
14 & CW & 65 & 80 & $23.08 \%$ \\
15 & IN & 64 & 88 & $37.50 \%$ \\
16 & ME & 55 & 76 & $38.18 \%$ \\
17 & NJ & 53 & 78 & $47.17 \%$ \\
18 & RAN & 56 & 70 & $25.00 \%$ \\
19 & TD & 67 & 86 & $28.36 \%$ \\
20 & YN & 59 & 78 & $32.20 \%$ \\
21 & DS & 68 & 75 & $10.29 \%$ \\
22 & MA & 66 & 80 & $21.21 \%$ \\
23 & NAR & 68 & 82 & $20.59 \%$ \\
24 & RR & 58 & 84 & $44.83 \%$ \\
25 & TR & 67 & 72 & $7.46 \%$ \\
& Rata-rata & 63 & 80.12 & $27.87 \%$ \\
\hline
\end{tabular}




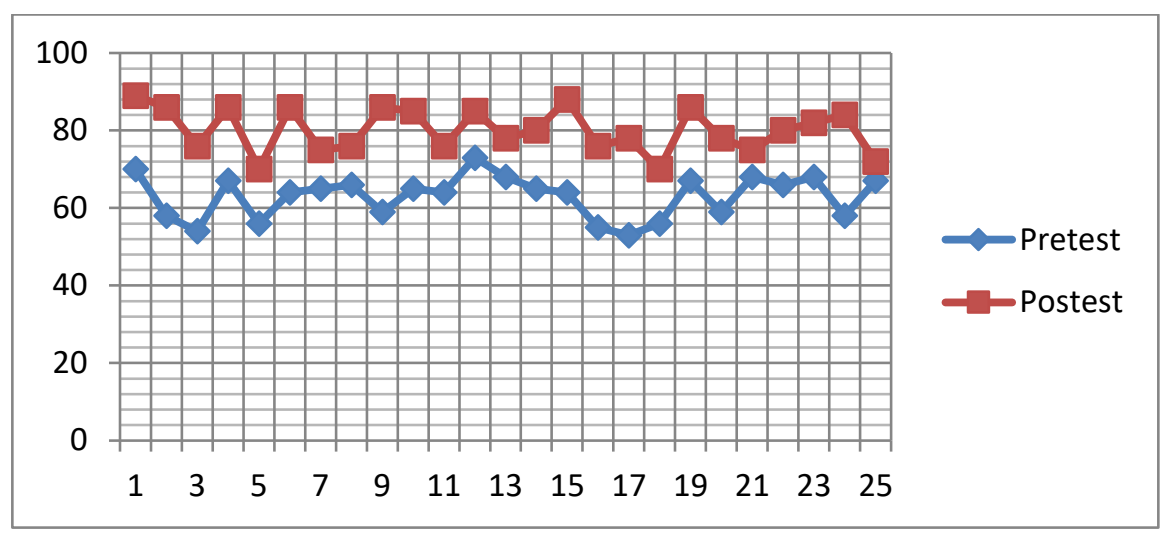

Gambar 2. Grafik peningkatan pretest-postest pada Indikator Guru dapat menerangkan teori pelajaran secara jelas pada anak

Tabel 3. Data Nilai Indikator Guru menggunakan pendekatan tertentu (STEAM) dg strategi , teknik, metode yg kreatif

\begin{tabular}{|c|c|c|c|c|}
\hline No & Nama & Pretest & Postest & Prosentase kenaikan \\
\hline 1 & $\mathrm{Al}$ & 56 & 86 & $53.57 \%$ \\
\hline 2 & $\mathrm{CN}$ & 67 & 75 & $11.94 \%$ \\
\hline 3 & DS & 59 & 76 & $28.81 \%$ \\
\hline 4 & FK & 68 & 86 & $26.47 \%$ \\
\hline 5 & $\mathrm{IF}$ & 66 & 85 & $28.79 \%$ \\
\hline 6 & LQN & 68 & 85 & $25.00 \%$ \\
\hline 7 & NNA & 58 & 76 & $31.03 \%$ \\
\hline 8 & $\mathrm{RF}$ & 54 & 85 & $57.41 \%$ \\
\hline 9 & RA & 70 & 78 & $11.43 \%$ \\
\hline 10 & $\mathrm{RH}$ & 58 & 80 & $37.93 \%$ \\
\hline 11 & TL & 54 & 88 & $62.96 \%$ \\
\hline 12 & AYN & 65 & 76 & $16.92 \%$ \\
\hline 13 & $\mathrm{CN}$ & 64 & 78 & $21.88 \%$ \\
\hline 14 & $\mathrm{CW}$ & 73 & 70 & $-4.11 \%$ \\
\hline 15 & IN & 68 & 86 & $26.47 \%$ \\
\hline 16 & ME & 65 & 78 & $20.00 \%$ \\
\hline 17 & NJ & 64 & 75 & $17.19 \%$ \\
\hline 18 & RAN & 55 & 80 & $45.45 \%$ \\
\hline 19 & TD & 53 & 82 & $54.72 \%$ \\
\hline 20 & YN & 67 & 84 & $25.37 \%$ \\
\hline 21 & DS & 56 & 72 & $28.57 \%$ \\
\hline 22 & MA & 64 & 89 & $39.06 \%$ \\
\hline 23 & NAR & 65 & 86 & $32.31 \%$ \\
\hline 24 & $\mathrm{RR}$ & 66 & 76 & $15.15 \%$ \\
\hline \multirow[t]{2}{*}{25} & $\mathrm{TR}$ & 59 & 86 & $45.76 \%$ \\
\hline & Rata-rata & 62.48 & 80.72 & $30.40 \%$ \\
\hline
\end{tabular}




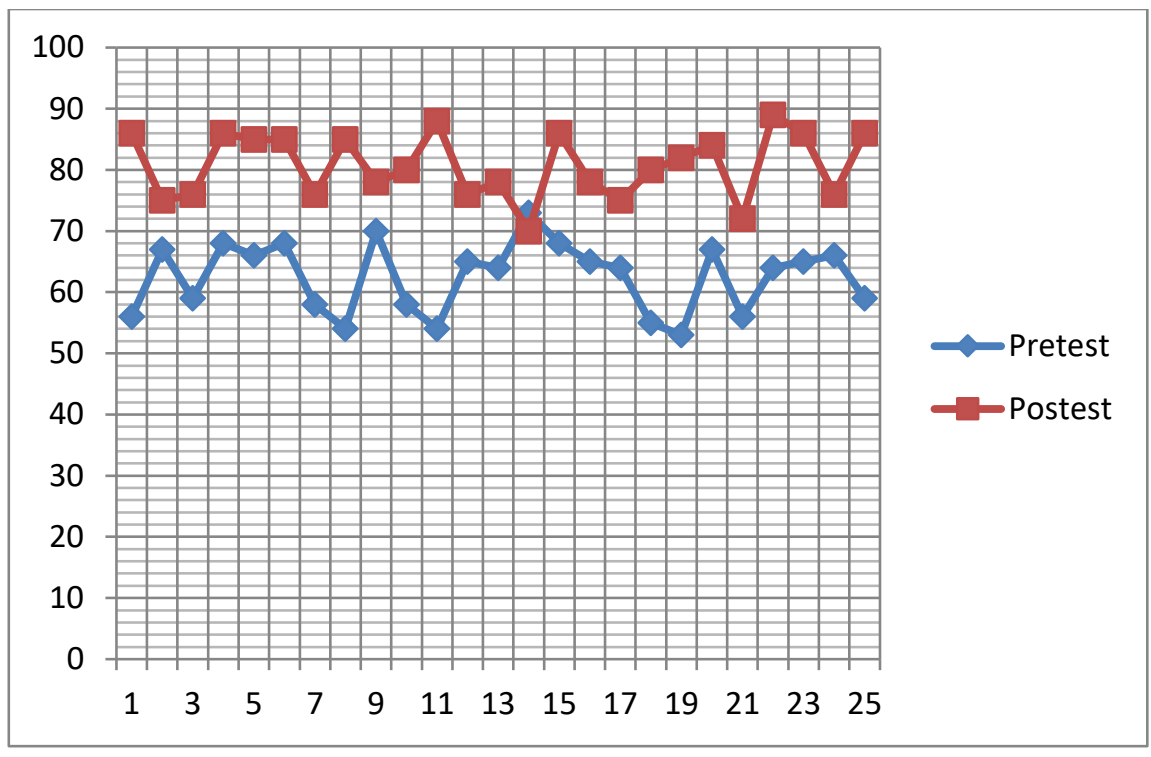

Gambar 3. Grafik peningkatan pretest-postest pada . Indikator Guru menggunakan pendekatan tertentu (STEAM) dg strategi , teknik, metode yg kreatif Data Nilai

Tabel 4. Data Nilai Indikator Guru mengembangkan kurikulum ( menyusun silabus, RPP sesuai kebutuhan)

\begin{tabular}{clccc}
\hline No & Nama & Pretest & Postest & Prosentase kenaikan \\
\hline 1 & Al & 67 & 88 & $31.34 \%$ \\
2 & CN & 59 & 76 & $28.81 \%$ \\
3 & DS & 68 & 78 & $14.71 \%$ \\
4 & FK & 66 & 70 & $6.06 \%$ \\
5 & IF & 68 & 86 & $26.47 \%$ \\
6 & LQN & 58 & 78 & $34.48 \%$ \\
7 & NNA & 54 & 75 & $38.89 \%$ \\
8 & RF & 70 & 80 & $14.29 \%$ \\
9 & RA & 58 & 82 & $41.38 \%$ \\
10 & RH & 54 & 84 & $55.56 \%$ \\
11 & TL & 67 & 72 & $7.46 \%$ \\
12 & AYN & 56 & 89 & $58.93 \%$ \\
13 & CN & 64 & 86 & $34.38 \%$ \\
14 & CW & 65 & 76 & $16.92 \%$ \\
15 & IN & 66 & 86 & $30.30 \%$ \\
16 & ME & 59 & 88 & $49.15 \%$ \\
17 & NJ & 65 & 76 & $16.92 \%$ \\
18 & RAN & 64 & 78 & $21.88 \%$ \\
19 & TD & 73 & 70 & $-4.11 \%$ \\
20 & YN & 68 & 86 & $26.47 \%$ \\
21 & DS & 65 & 78 & $20.00 \%$ \\
22 & MA & 64 & 75 & $17.19 \%$ \\
23 & NAR & 55 & 80 & $45.45 \%$ \\
24 & RR & 53 & 82 & $54.72 \%$ \\
25 & TR & 56 & 84 & $50.00 \%$ \\
& Rata-rata & 62.48 & 80.12 & $29.51 \%$ \\
\hline
\end{tabular}




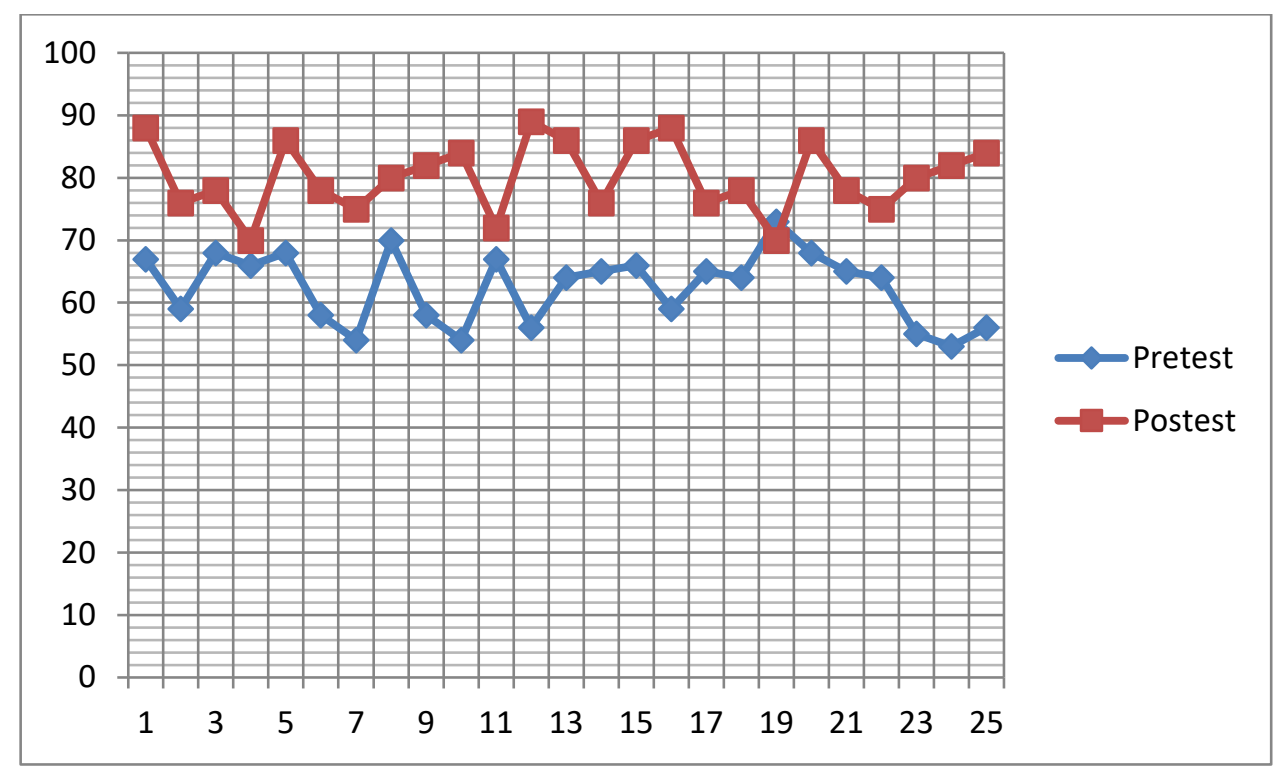

Gambar 4. Grafik peningkatan pretest-postest pada . Indikator Guru mengembangkan kurikulum ( menyusun silabus, RPP sesuai kebutuhan)

Tabel 5. Data Nilai Indikator Guru TDK sekedar menyampaikan pelajaran tetapi melakukan pendampingan

\begin{tabular}{clccc}
\hline No & Nama & Pretest & Postest & Prosentase kenaikan \\
\hline 1 & Al & 70 & 86 & $22.86 \%$ \\
2 & CN & 58 & 88 & $51.72 \%$ \\
3 & DS & 54 & 76 & $40.74 \%$ \\
4 & FK & 67 & 75 & $11.94 \%$ \\
5 & IF & 56 & 72 & $28.57 \%$ \\
6 & LQN & 64 & 81 & $26.56 \%$ \\
7 & NNA & 65 & 80 & $23.08 \%$ \\
8 & RF & 66 & 82 & $24.24 \%$ \\
9 & RA & 59 & 84 & $42.37 \%$ \\
10 & RH & 65 & 72 & $10.77 \%$ \\
11 & TL & 64 & 89 & $39.06 \%$ \\
12 & AYN & 73 & 86 & $17.81 \%$ \\
13 & CN & 68 & 76 & $11.76 \%$ \\
14 & CW & 65 & 86 & $32.31 \%$ \\
15 & IN & 64 & 88 & $37.50 \%$ \\
16 & ME & 55 & 76 & $38.18 \%$ \\
17 & NJ & 53 & 78 & $47.17 \%$ \\
18 & RAN & 56 & 70 & $25.00 \%$ \\
19 & TD & 67 & 86 & $28.36 \%$ \\
20 & YN & 59 & 78 & $32.20 \%$ \\
21 & DS & 68 & 75 & $10.29 \%$ \\
22 & MA & 66 & 80 & $21.21 \%$ \\
23 & NAR & 68 & 82 & $20.59 \%$ \\
24 & RR & 58 & 84 & $44.83 \%$ \\
25 & TR & 54 & 70 & $29.63 \%$ \\
& Rata-rata & 62.48 & 80 & $28.75 \%$ \\
\hline & & & & \\
\hline
\end{tabular}


Aulad : Journal on Early Childhood, 4(1) 2021, Pages 38-52

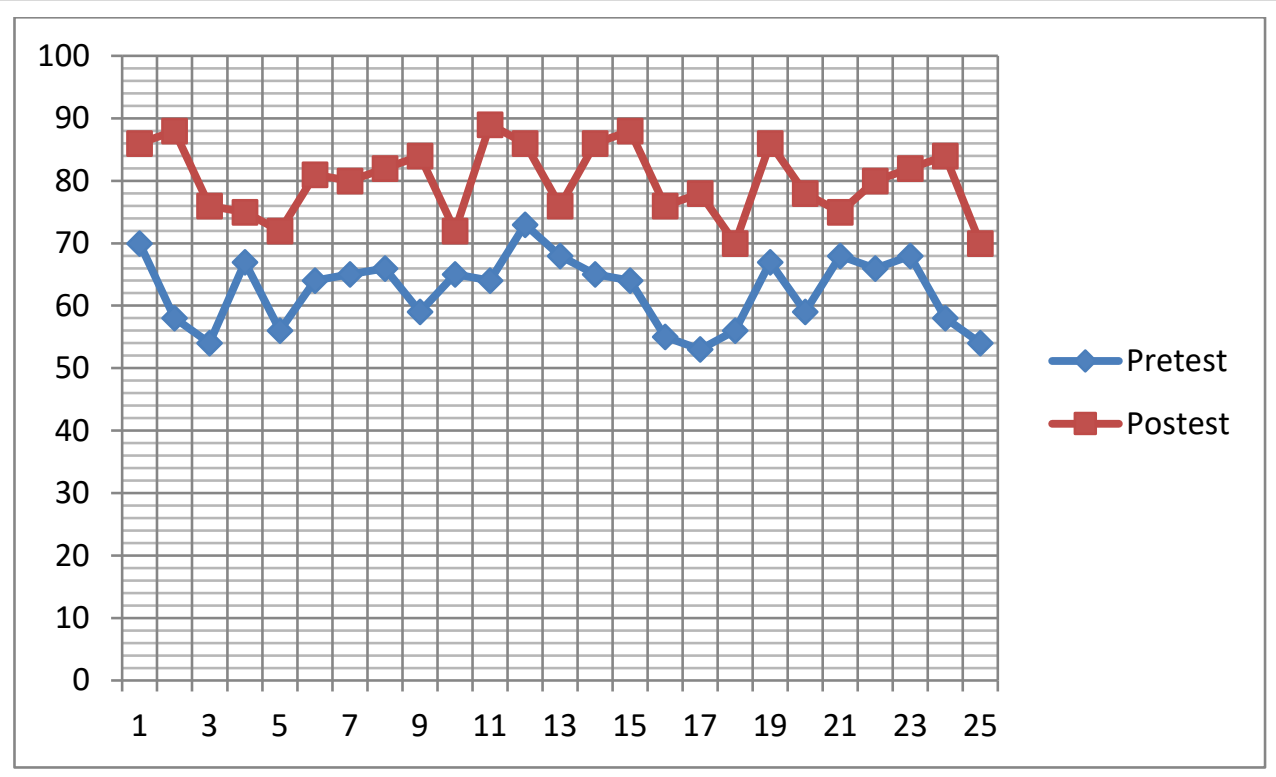

Gambar 5. Grafik peningkatan pretest-postest pada Indikator Guru TDK sekedar menyampaikan pelajaran tetapi melakukan pendampingan

Tabel 6. Data Nilai Indikator: guru mengembangkan potensi anak (peserta didik)

\begin{tabular}{clccc}
\hline No & Nama & Pretest & Postest & Prosentase kenaikan \\
\hline 1 & Al & 70 & 85 & $21.43 \%$ \\
2 & CN & 58 & 86 & $48.28 \%$ \\
3 & DS & 54 & 75 & $38.89 \%$ \\
4 & FK & 67 & 75 & $11.94 \%$ \\
5 & IF & 56 & 70 & $25.00 \%$ \\
6 & LQN & 64 & 80 & $25.00 \%$ \\
7 & NNA & 65 & 80 & $23.08 \%$ \\
8 & RF & 66 & 82 & $24.24 \%$ \\
9 & RA & 59 & 84 & $42.37 \%$ \\
10 & RH & 65 & 72 & $10.77 \%$ \\
11 & TL & 64 & 86 & $34.38 \%$ \\
12 & AYN & 73 & 86 & $17.81 \%$ \\
13 & CN & 68 & 76 & $11.76 \%$ \\
14 & CW & 65 & 88 & $35.38 \%$ \\
15 & IN & 64 & 87 & $35.94 \%$ \\
16 & ME & 55 & 76 & $38.18 \%$ \\
17 & NJ & 53 & 78 & $47.17 \%$ \\
18 & RAN & 56 & 70 & $25.00 \%$ \\
19 & TD & 67 & 84 & $25.37 \%$ \\
20 & YN & 59 & 79 & $33.90 \%$ \\
21 & DS & 68 & 75 & $10.29 \%$ \\
22 & MA & 66 & 80 & $21.21 \%$ \\
23 & NAR & 68 & 82 & $20.59 \%$ \\
24 & RR & 58 & 82 & $41.38 \%$ \\
25 & TR & 54 & 70 & $29.63 \%$ \\
& Rata-rata & 62.48 & 79.52 & $27.96 \%$ \\
\hline
\end{tabular}




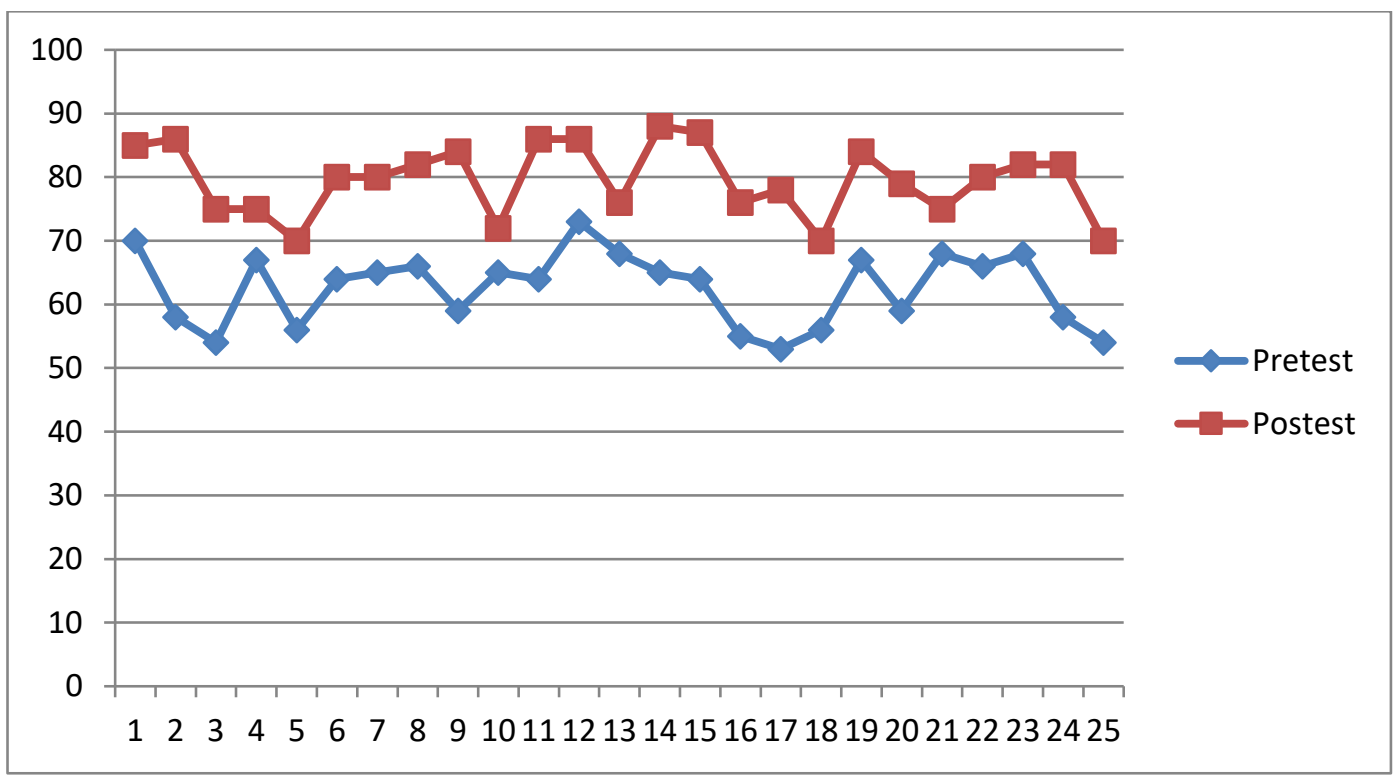

Gambar 6. Grafik peningkatan pretest-postest pada Indikator: guru mengembangkan potensi anak (peserta didik)

Tabel 7. Data Nilai Indikator Guru Memanfaatkan teknologi informasi dan komunikasi untuk kepentingan pembelajaran

\begin{tabular}{clccc}
\hline No & Nama & Pretest & Postest & Prosentase kenaikan \\
\hline 1 & Al & 70 & 82 & $17.14 \%$ \\
2 & CN & 58 & 86 & $48.28 \%$ \\
3 & DS & 54 & 75 & $38.89 \%$ \\
4 & FK & 67 & 75 & $11.94 \%$ \\
5 & IF & 56 & 72 & $28.57 \%$ \\
6 & LQN & 64 & 75 & $17.19 \%$ \\
7 & NNA & 65 & 80 & $23.08 \%$ \\
8 & RF & 66 & 82 & $24.24 \%$ \\
9 & RA & 59 & 84 & $42.37 \%$ \\
10 & RH & 65 & 72 & $10.77 \%$ \\
11 & TL & 64 & 86 & $34.38 \%$ \\
12 & AYN & 73 & 86 & $17.81 \%$ \\
13 & CN & 68 & 75 & $10.29 \%$ \\
14 & CW & 65 & 87 & $33.85 \%$ \\
15 & IN & 64 & 89 & $39.06 \%$ \\
16 & ME & 55 & 76 & $38.18 \%$ \\
17 & NJ & 53 & 78 & $47.17 \%$ \\
18 & RAN & 56 & 70 & $25.00 \%$ \\
19 & TD & 67 & 84 & $25.37 \%$ \\
20 & YN & 59 & 78 & $32.20 \%$ \\
21 & DS & 68 & 75 & $10.29 \%$ \\
22 & MA & 66 & 80 & $21.21 \%$ \\
23 & NAR & 68 & 82 & $20.59 \%$ \\
24 & RR & 58 & 84 & $44.83 \%$ \\
25 & TR & 54 & 70 & $29.63 \%$ \\
& Rata-rata & 62.48 & 79.32 & $27.69 \%$ \\
\hline & & & &
\end{tabular}




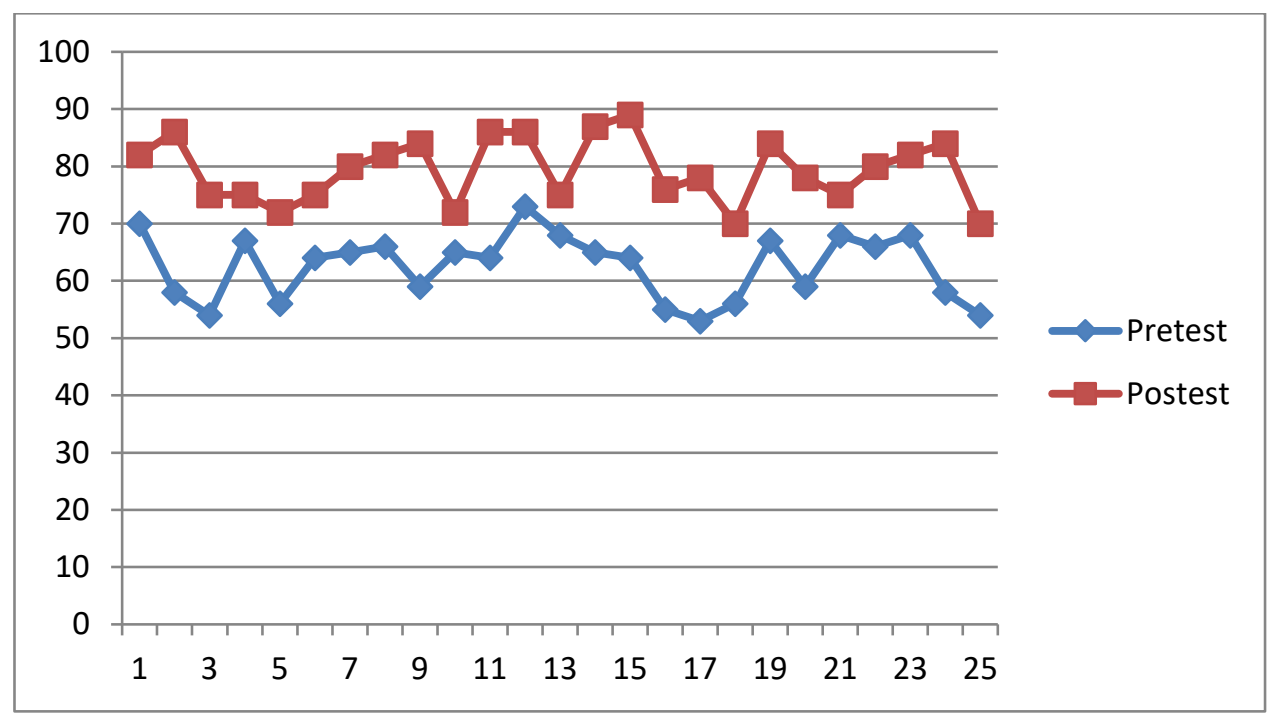

Gambar 7. Grafik peningkatan pretest-postest pada Indikator Guru Memanfaatkan teknologi informasi dan komunikasi untuk kepentingan pembelajaran

Tabel 8. Data Nilai Indikator: guru melakukan dan penilaian dan evaluasi terhadap efektivitas pembelajarsn yg dilakukan

\begin{tabular}{|c|c|c|c|c|}
\hline No & Nama & Pretest & Postest & Prosentase kenaikan \\
\hline 1 & $\mathrm{Al}$ & 70 & 85 & $21.43 \%$ \\
\hline 2 & $\mathrm{CN}$ & 58 & 88 & $51.72 \%$ \\
\hline 3 & DS & 54 & 75 & $38.89 \%$ \\
\hline 4 & FK & 67 & 75 & $11.94 \%$ \\
\hline 5 & IF & 56 & 72 & $28.57 \%$ \\
\hline 6 & LQN & 64 & 80 & $25.00 \%$ \\
\hline 7 & NNA & 66 & 84 & $27.27 \%$ \\
\hline 8 & RF & 66 & 82 & $24.24 \%$ \\
\hline 9 & RA & 60 & 84 & $40.00 \%$ \\
\hline 10 & $\mathrm{RH}$ & 65 & 72 & $10.77 \%$ \\
\hline 11 & TL & 64 & 85 & $32.81 \%$ \\
\hline 12 & AYN & 73 & 86 & $17.81 \%$ \\
\hline 13 & $\mathrm{CN}$ & 65 & 76 & $16.92 \%$ \\
\hline 14 & $\mathrm{CW}$ & 65 & 87 & $33.85 \%$ \\
\hline 15 & IN & 64 & 86 & $34.38 \%$ \\
\hline 16 & ME & 55 & 76 & $38.18 \%$ \\
\hline 17 & NJ & 53 & 78 & $47.17 \%$ \\
\hline 18 & RAN & 56 & 70 & $25.00 \%$ \\
\hline 19 & TD & 67 & 84 & $25.37 \%$ \\
\hline 20 & $\mathrm{YN}$ & 59 & 78 & $32.20 \%$ \\
\hline 21 & DS & 68 & 75 & $10.29 \%$ \\
\hline 22 & MA & 66 & 80 & $21.21 \%$ \\
\hline 23 & NAR & 66 & 82 & $24.24 \%$ \\
\hline 24 & $\mathrm{RR}$ & 58 & 83 & $43.10 \%$ \\
\hline 25 & $\mathrm{TR}$ & 54 & 70 & $29.63 \%$ \\
\hline
\end{tabular}




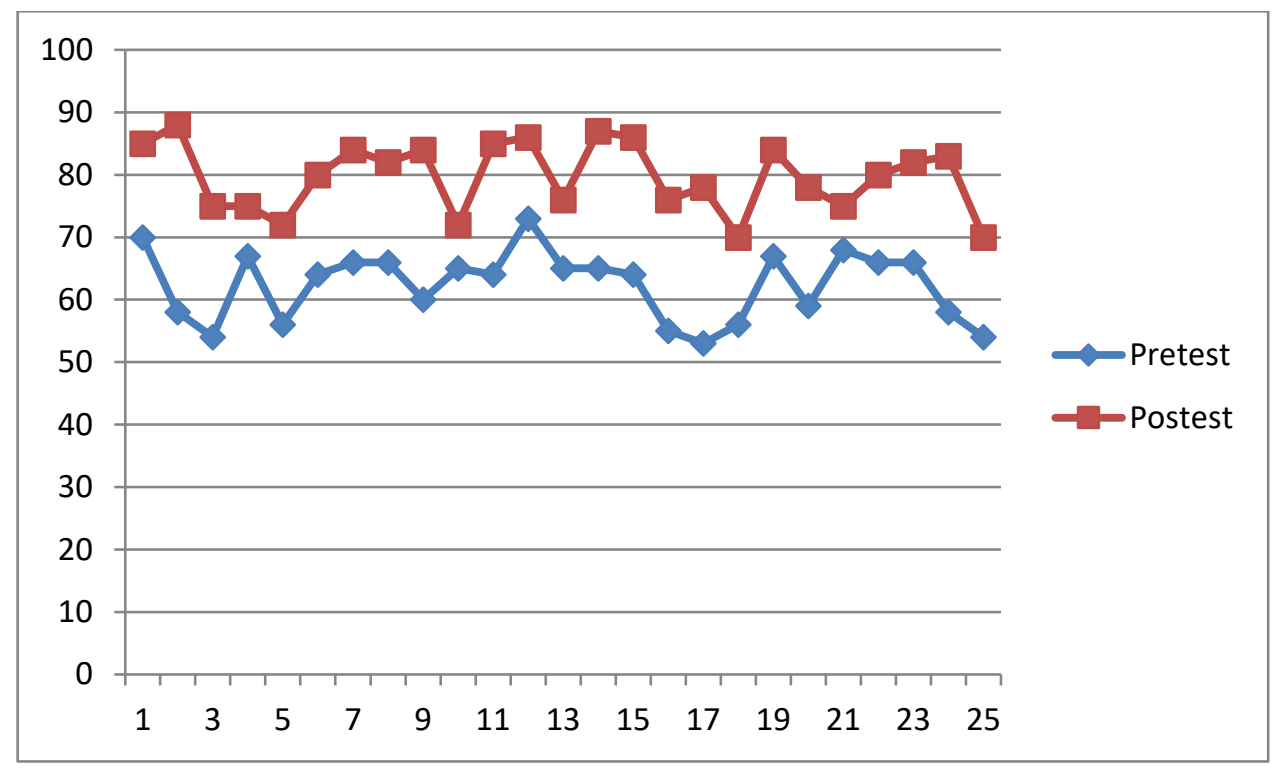

Gambar 7. Grafik peningkatan pretest-postest pada Indikator: guru melakukan dan penilaian dan evaluasi terhadap efektivitas pembelajarsn yg dilakukan

\section{Kesimpulan}

Setelah diberikan perlakuan, hasil posttest pada kompetensi guru pendidik anak usia dini menunjukkan bahwa terdapat peningkatan yang lebih besar pada kelas eksperimen dibandingkan dengan kelas kontrol. Kompetensi pedagogi guru pada pendidik anak usia dini pada kelas kontrol dan eksperimen setelah adanya perlakuan dilaksanakan adanya pencapaian pada kelas eksperimen lebih tinggi dibandingkan dengan kelas kontrol. Karena pada kelas eksperimen guru diberikaan pelatihan pendekatan STEAM kemudian diberikan pendampingan dalam mengamplikasikan pendekatan baru tersebut sehingga dapat meningkatkan kompetensi pedagogi mereka dalam pembelajaran jarak jauh kepada anak secara aplikatif dan nyata. Dimana aktivitas matematika adalah aktivitas yang di dalamnya terjadi proses pengabstraksian dari pengalaman nyata dalam Hasil penelitian menunjukkan bahwa tindakan pada kelas eksperimen yaitu pelatihan pendekatan STEAM mampu meningkatkan kompetensi pedagogi guru PAUD dibandingkan dengan kelas control.

\section{DAFTAR PUSTAKA}

Ananda, R. 2018. Profesi Pendidikan dan TenagaKependidikan. Medan. Lembaga Peduli Pengembangan Pendidikan Indonesia (LPPPI)

Asmuniv. 2015. Pendekatan Terpadu Pendidikan STEAM Upaya Mempersiapkan Sumber Daya Manusia Indonesia Yang Memiliki Pengetahuan Interdisipliner dalam Menyongsong Kebutuhan Bidang $\begin{array}{lll}\text { Karir Pekerjaan Masyarakat Ekonomi } & \text { ASEAN }\end{array}$ (http://www.vedcmalang.com/index.php/menuutama/listrikelectro/1507 -asv9), diakses 12 September 2017.

Birgili, B. 2015. Creative and Critical Thinking Skills in Problem-based Learning Environments. Journal of Gifted Education and Creativity, 2(2), 71-80 hlm. [Online], (https://files.eric.ed.gov/fulltext/ED563985.pdf), diakses September 2017.

Departemen Pendidikan Nasional Republik Indonesia.2005. Peraturan Pemerintah Republik Indo-nesia Nomor 19 Tahun 2005 Tentang Standar Nasional Pendidikan, Jakarta, h. 9

Fahrudin. U.A .2012. Menjadi Guru Faforit. Jogjakarta.DIVA Press. Guru Era 4.0", http://krjogja.com/ web/news/read/59981/Guru_Era_4_0, diakses 10 Desember 2018.

Hadinugraha dkk .2017. Keterampilan Abad 21 dan STEAM (Science, Technology, Engineering, Art and Mathematic) Project dalam Pembelajaran Kimia. Jakarta. LPPM UNJ. 
Kamil, M. 2012. Model-Model Pelatihan. Universitas Pendidikan Indonesia. Bandung.

"Ki Hadjar Dewantara dan Guncangan Pendidikan Era Industri 4.0", https://edukasi.kompas.com/ $\mathrm{read} / 2018 / 05 / 02 / 15561621 /$ kihadjar-dewantara-dan-guncanganpendidikan-era-industri-40, diakses 10 Desember 2018

Mahmudi, Ali. (2009). Mengembangkan Kompetensi Guru Melalui Lesson Study. Jurnal Forum Kependidikan, Volume 28, No. 2, Maret 2009.

Minan. A. 2013. Modul Pelatihan Teknologi of Participatory. Solo. Assisting Political Parties for Capacity Building (APPROACH)

Moh. Uzer Usman. 2003. Menjadi Guru profes-sional. Bandung: Rosda Karya, h. 5.4 E.

Mulyasa. 2004. Kurikulum Berbasis Kompeten-si: Konsep, Karakteristik, dan Implementasi,. Bandung: Remaja Rosdakarya, h. 38.5

Ningsih, A. M., Hidayat, D. R., Whitney, M., \& Sig, A. (2016). PENINGKATAN MOTIVASI BELAJAR SISWA ( Studi Kuasi Eksperimen Terhadap Siswa Kelas XI di SMA Negeri 59 Jakarta ) Abstrak. 5(1), 1-7 